\title{
ANIMALIA DUBIA VEL FABULOSA JAKO PRZYCZYNEK DO POLEMIKI ANTYHERETYCKIEJ W KOMENTARZU DO KSIĘGI IZAJASZA (VI 13, 19 - 14, 1) ŚW. HIERONIMA
}

Quidquid enim haeretici loquuntur in synagogis satanae, non est doctrina Domini, sed ululatus daemonum ${ }^{1}$.

Przyrodnicze dzieła greckich i rzymskich naturalistów obfitują w nadzwyczajne i zdumiewające opisy zachowań przedstawicieli fauny ${ }^{2}$. Ogromna popularność takich niezwykłych opowieści o egzotycznych zwierzętach, żyjących często w odległych krainach, doprowadziła do powstania szczególnego typu piśmiennictwa, które badacze antyku zwykli określać mianem literatury paradoksograficznej ${ }^{3}$. Te niewiarygodne, często przejaskrawione i wypaczone obrazy zwierząt egzotycznych o wątpliwej identyfikacji lub zoomorficznych istot mitycznych, takich jak gryf, feniks, bazyliszek, centaur czy syrena, dostarczyły Ojcom Kościoła materiału, dzięki któremu powstać mogło wiele dzieł homiletycznych czy egzegetycznych ${ }^{4}$. Zwierzęta bowiem - również te, których istnienie stało pod znakiem zapytania - pojawiały się w Septuagincie, Wulgacie oraz innych przekładach greckich i łacińskich, a przecież starożytni

${ }^{*}$ Mgr Łukasz Krzyszczuk - doktorant przy Pracowni Starożytnego Bliskiego Wschodu i Tradycji Biblijnej w Instytucie Studiów Klasycznych, Śródziemnomorskich i Orientalnych na Wydziale Filologicznym Uniwersytetu Wrocławskiego; e-mail: lukasz.krzyszczuk@uwr.edu.pl.

${ }^{1}$ Hieronymus, Commentarii in Esaiam VI 13, 19 - 14, 1, ed. R. Gryson - J. Coulie: Commentaires de Jérôme sur le prophetè Isaïe, vol. 2: Livres V-VII, Vetus Latina. Aus der Geschichte der Lateinischen Bibel [= VL] 27, Freiburg 1994, 714.

${ }^{2}$ Niezwykłe opisy fauny i flory znajdujemy już u historyków takich jak Herodot i znany nam pośrednio Ktezjasz z Knidos. Jednak dzieła stricte przyrodnicze pozostawili po sobie autorzy tacy jak Arystoteles, Teofrast z Eresos, Klaudiusz Elian, Plutarch, czy na gruncie łacińskim Pliniusz Starszy. Więcej na temat Herodotowych opisów gryfów por. K. Mikoś, Wiarygodność najstarszych przekazów greckich o Arimaspach i „ich” gryfach. Aristeasz, Herodot i kwestia starego Prokonne$z u$, w: Istoty hybrydalne i zmieniajace postać w kulturach europejskich i azjatyckich, red. K. Mikoś - K. Kleczkowska, Kraków 2015, 45-78.

${ }^{3}$ Por. S. Kazikowski, Paradoksografia, w: Mała encyklopedia kultury świata antycznego, II, Warszawa 1962, 155.

${ }^{4}$ Por. np. L. Fonck, Hieronymi scientia naturalis exemplis illustratur, „Biblica” 1 (1920) fasc. 4 , 481-499. 
pisarze chrześcijańscy z tych thumaczeń Pisma Świętego nieustannie czerpali inspiracje dla swoich nauk moralnych, te teksty komentowali i nad nimi dyskutowali. Nie może nas przecież dziwić, że spotykając w tekście biblijnym istoty o watpliwej identyfikacji lub mitologiczne, wychowani na Homerze starożytni chrześcijańscy pisarze, często sięgali - pośrednio bądź bezpośrednio do Arystotelesa czy Pliniusza Starszego ${ }^{5}$. Zazwyczaj wyjaśnienia pogańskich naturalistów wykorzystywali Ojcowie Kościoła do wysnucia jakiejś nauki moralnej lub budowania egzegezy alegorycznej. W ten sposób konstruktywnie rozwiązywali trudny problem obecności w świętych tekstach istot znanych z pogańskiej mitologii.

W niniejszym artykule przyjrzymy się wykorzystaniu przez Hieronima ze Strydonu tego typu informacji na temat istot mitologicznych oraz zwierząt o wątpliwej identyfikacji, które umownie nazwać możemy fantastycznymi ${ }^{6}$, w prowadzeniu polemiki antyheretyckiej w szóstej księdze Komentarza do Księgi Izajasza. Przy tej okazji przebadamy także obecną tam polemikę antyjudaistyczną, która występuje w innych komentarzach Ojca Wulgaty często obok wątków antyheretyckich.

\section{1. Źródła alegorycznego wyjaśniania zachowań i fizjonomii zwierząt} fantastycznych. Oczywiście Hieronim nie był pierwszym autorem, który niektóre zachowania, cechy czy opisy zwierząt fantastycznych przypisał postępowaniu heretyków. Dla przykładu, żyjący w II lub IV w. anonimowy chrześcijań-

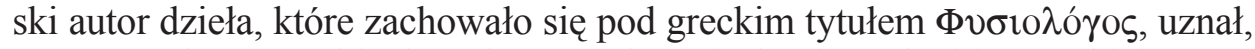
że z powodu niezwykłych cech znanych z mitologii greckiej i rzymskiej, istoty takie jak syreny i hippocentaury trafnie obrazują heretyków:

„Prorok Izajasz powiedział, że demony, syreny i jeże będą tańczyć w Babilonie. Fizjolog tak rzekł o syrenach i hippocentaurach. W morzu żyją zwierzęta zwane syrenami, które podobnie jak Muzy śpiewają melodyjnym głosem. Gdy przepływający w pobliżu usłyszą ich śpiew, rzucają się w morze i giną. Połowa ciała syren, poczynając od pępka, przybiera kształt ludzki, druga połowa zaś - gęsi. Podobnie hippocentaury: połowę ciała mają podobną do człowieka, drugą połowę zaś, począwszy od piersi - podobną do konia. Tak też każdy człowiek o dwoistym sercu jest niestały we wszystkich swych drogach.

${ }^{5}$ Kwestia bezpośredniej znajomości dzieł naturalistów przez poszczególnych Ojców Kościoła jest dyskutowana przez uczonych. Por. np. H. Hagendahl, Latin Fathers and the Classics. A Study on the Apologists, Jerome and Other Christian Writers, Studia Graeca et Latina Gothoburgensia 6, Göteborg 1958.

${ }^{6}$ Za Samuelem Bochartem (1599-1667), który ostatnią księgę drugiego tomu dzieła pt. Hierozoicon sive de animalibus sacrae Scripturae z 1663 r. poświęcił zwierzętom dubiis sive fabulosis, wielu współczesnych uczonych określa zoonimy biblijne, z których identyfikacją w Biblii Hebrajskiej lub w jej starożytnych przekładach są problemy, mianem zwierząt fantastycznych, zwierząt o wątpliwej identyfikacji, zwierząt nierealnych, istot mitycznych itp. Por. R.M. Grant, Early Christians and Animals, London - New York 2001, 34-43. 
Są tacy, którzy po przyjęciu do Kościoła wykazują pozory pobożności, lecz wyrzekają się jej istoty. W Kościele zachowują się jak ludzie, kiedy jednak oddzielą się od Kościoła, zamieniają się w dzikie zwierzęta. Są oni zatem podobni do syren i hippocentaurów, czyli nieprzyjacielskich mocy i szyderczych heretyków. Poprzez piękne słówka i krasomówstwo tak jak syreny oszukują bowiem serca nieznających zła. «Dobre zwyczaje ulegają zepsuciu poprzez złe towarzystwo» (1Kor 15, 33). Dobrze zatem powiedział Fizjolog o syrenach i hippocentaurach"7.

Autor Fizjologa, odnosząc się do Iz 13, 21, w skróconej formie przytoczył na początku powszechnie znane w antyku hybrydalne cechy syren i hippocentaurów, a następnie odniósł je do dwoistości serca i niestałości poglądów chrześcijan, którzy odstępują od wiary. Chrześcijański przyrodnik nie omieszkał wykorzystać w swojej antyheretyckiej naganie również motywu słodkiego, ale prowadzącego do śmierci, syreniego śpiewu. Do niego bowiem według Twórcy Fizjologa podobne są retoryczne sztuczki heretyków, które mogą do upadku przywieść niedoświadczonych.

Wykorzystany przez anonimowego autora Fizjologa rozdział trzynasty Księgi Izajasza, gdzie czytamy o skrajnym wyludnieniu miasta Babilon, wykorzystał również św. Hieronim. Zanim jednak szerzej się przyjrzymy objaśnieniom Ojca Wulgaty, przybliżmy w kilku słowach ratio hermeneutyczną, którą kierował się egzegeta ze Strydonu, komentując księgi prorockie.

2. Hieronimowa egzegeza dosłowna Iz 13, 19 - 14, 1. Komentarze do proroków są najobszerniejszymi i według niektórych patrologów najważniejszymi dziełami egzegetycznymi św. Hieronima ${ }^{8}$. Objaśniając starotestamentowych proroków Strydończyk, wzorem Orygenesa, po przywołaniu perykopy biblijnej, przechodzi do komentarza dosłownego, w którym zwykle 1) stara się nakreślić przed czytelnikiem sytuację historyczną i społeczno-kulturową starożytnego Izraela, w której przyszło danemu prorokowi działać oraz 2) podaje uwagi filologiczne, o których więcej zostanie powiedziane poniżej. Po egzegezie dosłownej buduje Hieronim alegorezę ${ }^{9}$. W tej drugiej warstwie komentarza do danej perykopy ojciec Wulgaty, opierając się na objaśnieniu literalnym, przedstawia najczęściej zalecenia moralne, porusza kwestie chrystologiczne czy eschatologiczne. Tutaj też znajdują się na tyle częste w komentarzach do proroków interesujące nas uwagi antyheretyckie, że John Norman Davidson Kelly wskazuje

${ }^{7}$ Physiologus I 13, 1-3, ed. F. Sbordone: Physiologi Graeci singulae variarum aetatum recensiones codicibus fere omnibus tunc primum excussis collatisque, Mediolani 1936, 35-36, thum. K. Jażdżewska: Fizjolog, Warszawa 2003, 35.

${ }^{8}$ Por. F. Drączkowski, Patrologia, Pelplin 2012, 311.

${ }^{9}$ Alegoreza to metoda hermeneutyczna, polegająca na wydobywaniu z komentowanego tekstu biblijnego znaczeń, które nie były intencją autora. Więcej o ponaddosłownym sensie wydobywanym przez Ojców Kościoła z Pisma Świętego por. K. Bardski, Alegoryczno-symboliczna interpretacja Biblii, Kraków 2016, 17-29. 
na nie jako na jeden z podstawowych tematów Hieronimowej alegorezy ${ }^{10}$. Tematyka antyheretycka często przewija się w interesującym nas Komentarzu do Ksieggi Izajasza ${ }^{11}$. Fakt, że w osiemnastu księgach najobszerniejszego dzieła egzegetycznego Ojca Wulgaty łacińskie słowo haerĕtĭcus występuje aż 129 razy, podkreśla zainteresowanie Strydończyka polemiką antyheretycką.

Św. Hieronim w komentarzach do proroków mniejszych, kiedy przywołuje perykopę biblijną którą ma zamiar komentować, każdorazowo podaje przekład z języka hebrajskiego oraz przełożoną na łacinę wersję Septuaginty - oba tłumaczenia są dokonane osobiście przez Ojca Wulgaty. W Komentarzu do Księgi Izajasza, z uwagi na objętość materiału, nie jest już tak konsekwentny ${ }^{12}$. Podaje łaciński przekład Septuaginty tylko wtedy, kiedy znacznie odbiega od thumaczenia tekstu hebrajskiego. Tak właśnie według Hieronima jest w przypadku interesującego nas passusu z trzynastego rozdziału Księgi Izajasza. Strydończyk przywołuje dwa dokonane przez siebie tłumaczenia Iz 13, 19 - 14, 1:

„«I będzie Babilon, on sławny wśród królestw, znany z pychy Chaldejczyków, jak Bóg obalił Sodomę i Gomorę. Nie będzie zamieszkany aż do końca, z pokolenia na pokolenie, i nie rozbije tam Arab swoich namiotów ani nie będą tam wypoczywać pasterze. Ale będą tam wypoczywać dzikie zwierzęta i wypełnią domy ich smoki, zamieszkiwać tam będą strusie i kosmacze skakać tam będą. Będą tam odpowiadać sobie puszczyki w jego budynkach i syreny w świątyniach przyjemności. Blisko jest, aby nadszedł jego czas, a dni jego nie zostaną odwleczone». Septuaginta: «I będzie Babilon, który jest nazywany znanym królestwem Chaldejczyków, jak Bóg obalił Sodomę i Gomorę. Na wieki nie będzie zamieszkany, ani nie wstąpią do niego przez mnóstwo pokoleń. I nie przejdą przez niego Arabowie, a pasterze nie będą w nim wypoczywać. Ale będą tam wypoczywać dzikie zwierzęta i napełnią domy dźwiękiem, będą tam leżeć syreny i demony skakać tam będą. Onocentaury tam zamieszkają i jeże uczynią legowiska w jego domach. Szybko nadchodzi i nie spóźni się»"13.

${ }^{10}$ Por. J.N.D. Kelly, Hieronim. Życie, pisma, spory, thum. R. Wiśniewski, Warszawa 2003, 255.

${ }^{11}$ Najobszerniejszy z komentarzy św. Hieronima powstał zasadniczo w latach 406-410. Więcej na temat Komentarza do Księgi Izajasza, por. J. Jay, L'exégèse de Saint Jérôme d'après son „Commentaire sur Isaïe”, Paris 1985; R. Maisano, L'esegesi di Girolamo ad Isaia, w: Seminario interdisciplinare sul libro del profeta Isaia, ed. R. Maisano - V. Mangogna, Napoli 2007, 101-146; Ł. Krzyszczuk, Wstęp, w: Św. Hieronim, Komentarz do Księgi Izajasza X 34, 1 - X 35, 10 (Commentarii in Esaiam, CPL 584), VoxP 36 (2016) t. 66, 529-532.

${ }^{12}$ Por. Hieronymus, Commentarii in Esaiam I Prol., ed. R. Gryson - P.-A. Deproost: Commentaires de Jérôme sur le prophetè Isaïe, vol. 1: Livres I-IV, VL 23, Freiburg 1993, 139: „Sicubi autem praetermissis LXX de hebraico disputavi, illud in causa est quod aut eadem aut similia sunt pleraque cum ceteris et duplici editione proposita nolui libros explanationis extendere, qui etiam in simplici explanatione modum brevitatis excedunt".

${ }^{13}$ Tamże VI 13, 19 - 14, 1, VL 27, 709-710, thum. własne. 
Pobieżna nawet analiza obu przywołanych przez św. Hieronima przekładów interesującej nas perykopy ujawnia znaczne rozbieżności jeśli chodzi o nazwy istot zamieszkujących ruiny Babilonu. Problem ten ilustruje poniższa tabela ${ }^{14}$ :

\begin{tabular}{|c|c|c|c|}
\hline $\begin{array}{c}\text { Slowo } \\
\text { greckie użyte } \\
\text { w Septuagincie }\end{array}$ & $\begin{array}{c}\text { Przekład polski } \\
\text { rzeczownika } \\
\text { greckiego }\end{array}$ & $\begin{array}{l}\text { Słowo lacińskie } \\
\text { użyte w Wulgacie }\end{array}$ & $\begin{array}{c}\text { Przekład polski } \\
\text { rzeczownika } \\
\text { lacińskiego }\end{array}$ \\
\hline$\theta \eta p^{\prime} \alpha$ & dzikie zwierzęta & bestiae & dzikie zwierzęta \\
\hline$\grave{n} \chi 0 v$ & dźwięk & draconibus & smoki / węże \\
\hline 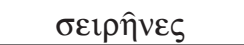 & syreny & strutiones & strusie \\
\hline$\delta \alpha \imath \mu o ́ v i \alpha$ & demony & pilosi & kosmacze \\
\hline 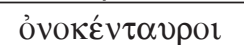 & onocentaury & ululae & puszczyki \\
\hline 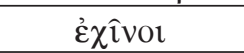 & jeże & sirenae & syreny \\
\hline
\end{tabular}

Po przywołaniu perykopy Strydończyk przechodzi do komentarza dosłownego, który tutaj ma charakter przede wszystkim filologiczny:

„«Nie będą tam wypoczywać pasterze», którzy mają w zwyczaju wypasać najłagodniejsze stado Pana w Jerozolimie, lecz przeciwnie: będą tam wypoczywać zwierzęta, których lękał się Psalmista, mówiąc: «Nie wydawaj zwierzętom duszy wyznającej Ciebie» (Ps 73, 19). W ich miejsce Akwila, Symmach i Teodocjon pozostawili samo słowo hebrajskie siim $^{15}$. I zostaną napełnione domy ich, to jest Babilończyków, według Septuaginty i Teodocjona dźwiękiem i hałasami (sonitu et clamoribus); według Akwili tyfonami (typhonibus), które my przełożyliśmy na smoki (dracones); u Symmacha zostało pozostawione hebrajskie słowo oim $^{16}$. «I zamieszkiwać tam będą strusie (struthiones)», zwierzę nieustannie szukające samotności, które zostało dokładniej opisane w Księdze Hioba (por. Hi 39, 13-18). Chociaż wydaje się, że ma pióra, to wyżej nad ziemię nie unosi się. Przez Septuagintę zostały przetłumaczone na syreny (sirenas). Kosmaczy (pilosos) zaś, których nazywa się po hebrajsku seirim ${ }^{17}$, Teodocjon przetłumaczył na wyprostowanych i o stojących włosach (erectis et stantibus pilis). Symmach i Septuaginta przetłumaczyli jako demony (daemonas). Także jeśli chodzi o onocentaury (onocentauris), jak jedynie Septuaginta tłumaczy, mają być podobne do tych, wywodzących się z bajek narodów, które powiadają, że były hippocentaury (imitantes gentilium fabulas, qui dicunt fuisse hippocentauros). Trzej pozostali thumacze

${ }^{14} \mathrm{~W}$ tabeli słowa greckie i łacińskie pozostawiono w takiej liczbie i takim przypadku, w jakich występują w tekście greckim i łacińskim perykopy. Tłumaczenia polskie uwzględniają jedynie liczbę rzeczownika. Tekst grecki za: Septuaginta, id est Vetus Testamentum graece iuxta LXX interpretes, ed. A. Rahlfs, Stuttgart 1979, 584. Tekst łacińska za: Biblia Sacra iuxta Vulgatam versione, ed. R. Weber - R. Gryson, Stuttgart 20135, 1110.

${ }^{15}$ Hebr. צִיים.

${ }^{16}$ Hebr. אזרחים.

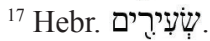


pozostawili słowo hebrajskie ihim $^{18}$, które my tłumaczymy na puszczyki (ululas). Skoro zaś Septuaginta mówi: «w domach ich uczynią sobie legowiska jeże (ericii)», a w hebrajskim oddane jest to przez thennim ${ }^{19}$, Akwila, Symmach i Teodocjon oddali [to] jako syreny (sirenas), wskazując, że są to albo jakieś zwierzęta (significantes bestias aliquas) albo demony, które śpiewają słodko i oszukują ludzi, którzy nie mogą przejść przez sztorm tego świata z zamkniętymi uszami. Skoro zaś nazwa onocentaurów została utworzona z osłów i centaurów (onocentauri nomen, ex asinis centaurisque compositum) wydaje mi się, że oznacza tych, którzy w części myślą po ludzku, lecz dla przyjemności i niemoralnych biesiad popadają w błędy"20.

Komentując różnice pomiędzy swoim przekładem z języka hebrajskiego a wersją Septuaginty, św. Hieronim przywołuje brzmienie słów hebrajskich ${ }^{21}$ oraz inne przekłady greckie - Akwili, Symmacha i Teodocjona ${ }^{22}$. W komentarzu Ojca Kościoła dostrzegamy, spowodowane pośpiechem ${ }^{23}$, pobieżne potraktowanie owych ciekawych rozbieżności filologicznych, które całkowicie zmieniają sens. Strydończyk zadowala się wyszczególnieniem jak dany zoonim przełożył Akwila, jak Symmach, jak Teodocjon, jak Septuaginta oraz jak brzmi słowo hebrajskie. Nie próbuje zająć stanowiska, ani nawet nie skłania się z namysłem ku którejś wersji. Oto mówi na przykład, że opuszczone domostwa Babilończyków napełnią się, według wersji Septuaginty i Teodocjona dźwiękiem i hałasami, a według Akwili tyfonami. Powiada też, że Symmach nie przetłumaczył użytego w tym miejscu tego rzeczownika hebrajskiego ${ }^{24}$,

\footnotetext{
${ }^{18}$ Hebr. אִּיִים

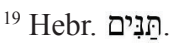

${ }^{20}$ Hieronymus, Commentarii in Esaiam VI 13, 19 - 14, 1, VL 27, 711-712, tłum. własne.

${ }^{21}$ Por. A. Yuditsky, Jerome's transcriptions of Hebrew. A reexamination, „Lešonenu” 76 (2014) 121-136.

${ }^{22}$ Są to przekłady greckie, które obok Septuaginty znalazły się w słynnych Heksaplach - zredagowanego przez Orygenesa w sześciu kolumnach Starego Testamentu. Poza owymi czterema przekładami greckimi znalazł się tam jeszcze tekst hebrajski i jego grecka transliteracja. Więcej na temat znaczenia Heksapli w pracy translatorskiej nad Biblią św. Hieronima, por. A. Thibaut, La revision hexaplaire de Saint Jérôme, w: Richesses et deficiences des anciens psautiers latins, ed. P. Salmon, Collectanea Biblica Latina 13, Roma 1959, 107-150. Ojciec Wulgaty bardzo często powołuje się w swojej twórczości egzegetycznej na przekłady Akwili i Symmacha oraz na dokonaną przez Teodocjona rewizję Septuaginty. W czasach Hieronima przekłady heksaplarne cieszyły się popularnością. Zob. Hieronymus, Prologus in librum Esaiae, ed. Weber - Gryson, w: Biblia Sacra iuxta Vulgatam versionem, s. 1096: ,[...] nihilominus hoc a fastidiosis lectoribus precor, ut quomodo Graeci post Septuaginta translatores Aquilam et Symmachum et Theodotionem legunt vel ob studium doctrinae suae vel ut Septuaginta magis ex conlatione eorum intelligant".

${ }^{23}$ Św. Hieronim wiele swoich dzieł pisał w pośpiechu. Np. liczące osiemnaście tysięcy słów (więcej niż Komentarz do Księgi Aggeusza) dziełko polemiczne pt. Przeciw Wigilancjuszowi powstało w jedną noc. Por. Hieronymus, Contra Vigilantium 17, ed. J.-L. Feiertag, CCL 79C, Turnhout 2005, 30, tłum. G. Rurański, w: Św. Hieronim ze Strydonu, Pisma polemiczne. Przeciw Helwidiuszowi. Przeciw Jowinianowi. Przeciw Wigilancjuszowi, ŹM 67, Kraków 2013, 457.

${ }^{24} \mathrm{Tj}$. hebr. rzeczownika אָג, który pojawia się w tym miejscu w liczbie mnogiej i brzmi אחָים
} 
a sam Hieronim przełożył ten termin inaczej niż wszyscy, mianowicie na smoki (dracones). Wydaje się, że pod wpływem przekładu Akwilii ${ }^{25}$ hebrajski

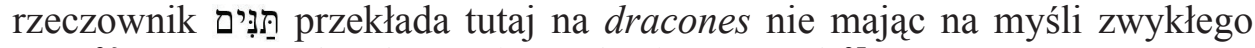
węża ${ }^{26}$, a monstrualnych rozmiarów latającego gada ${ }^{27}$.

Ojciec Wulgaty wypowiada się także na temat obecnych w Septuagincie onocentaurów i syren - tych samych istot, które zainteresowały Autora Fizjo$\log a$. Pierwsza uwaga Strydończyka może wydawać się deprecjonującą krytyką zasadności przekładu Septuaginty. Mówi Hieronim, że spośród wszystkich przekładów heksaplarnych jedynie Septuaginta dokonuje takiego wyboru translatorskiego oraz że istnienie onocentaurów, pół osłów, pół ludzi, stoi pod znakiem zapytania - podobnie jak w przypadku pokrewnych im hippocentaurów moga to być jedynie bajki, wymysły narodów pogańskich. Ponadto Hieronim proponuje, zdaje się, mniej fantastyczny zoonim w miejsce onocentaurów, mianowicie puszczyki. Czy jednak Hieronim próbuje świadomie odmitologizować Septuagintę? Nic podobnego. Przeanalizowaliśmy powyżej

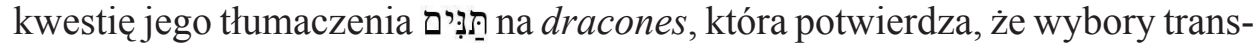
lacyjne Strydończyka nie są pokierowane chęcią demitologizacji Septuaginty. Dodatkowo kolejny zoonim pojawiający się w tekście Izajasza według Septuaginty, mianowicie zwyczajne jeże, zdecydował się ojciec Wulgaty zamienić na syreny, które wybiera ze względu na thumaczenia Akwili, Symmacha i Teodocjona. Strydończyk co prawda dopuszcza myśl, że syreny mogą być zwierzętami, ale równie dobrze mogą być według niego demonami - ponownie Ojciec Kościoła nie mówi, co jest bardziej prawdopodobne.

3. Hieronimowa egzegeza alegoryczna Iz 13, 19 - 14, 1. W tym miejscu komentarza Hieronim płynnie przechodzi od analizy filologicznej ku alegorezie, na razie pozwalając sobie jedynie na pouczenia o charakterze moralnym.

${ }^{25}$ Więcej o wpływie przekładu Starego Testamentu Akwili z Synopy na wybory translatorskie św. Hieronima, zob. J.R. Labendz, Aquila's Bible Translation in Late Antiquity. Jewish and Christian Perspectives, HTR 102 (2009) fasc. 3, 383-386; M. Graves, Jerome's Hebrew Philology. A Study Based on His Commentary on Jeremiah, Supplements to VigCh 90, Leiden - Boston 2007, 92-128. Sarah Kamin (The Theological Significance of the Hebraica Veritas in Jerome's Thought, w: ,, Sha'arei Talmon”. Studies in the Bible, Qumran, and the Ancient Near East Presented to Shemaryahu Talmon, ed. M. Fishbane - E. Tov - W.W. Fields, Winona Lake 1992, 252) uważa, że Strydończyk cenił tłumaczenie Akwili bardziej niż Septuagintę.

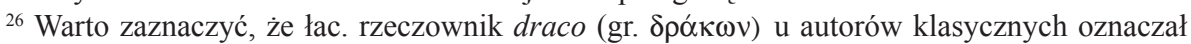
przede wszystkim węża większego niż serpens (Plezia II 250-251, s.v. draco; Abramowiczówna

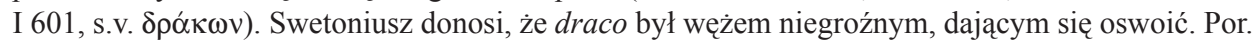
Gaius Svetonius Tranquillus, De vita Caesarum, Tiberius 72, ed. M. Ihm: C. Suetoni Tranquillli Opera, vol. 1: De vita Caesarum libri VIII, Leipzig 1908, 150, tłum. J. Niemirska-Pliszczyńska: Gajusz Swetoniusz Trankwillus, Żywoty Cezarów, t. 1, Wrocław 2004, 271.

${ }^{27}$ Por. Hieronymus, Commentarii in Esaiam V 13, 20-22, VL 27, 560: „Sirenae autem thennim vocantur, quas nos aut daemones aut monstra quaedam vel certe dracones magnos interpretabimur, qui cristati sunt et volantes". Zob. A. Heyman, Sirens Chanting in Auvergne-Velay. A Story of Exegetical Pilgrimage on the Via Podiensis, „Ad Limina” 4 (2013) fasc. 4, 82. 
Odwołując się do przysłowiowego syreniego śpiewu poucza, że ten, kto nie zamyka uszu na pokusy demonów, nie uniknie rozbicia i nie zwycięży świata. Następnie Hieronim wraca do onocentaurów, których hybrydalną nazwę tłumaczy alegorycznie ludzką skłonnością dwoistego serca, które wybiera grzech nad mądrość Bożą. Ten, kto ulega pokusom, popada w błąd. Również w tej części komentarza dostrzegamy, że ojciec Wulgaty nie zastanawia się nad realnością istnienia syren i onocentaurów. Po prostu chętnie wykorzystuje przypisywane im przez kulturę antyczną i powszechnie znane cechy do tworzenia alegorezy. Zabieg taki jest zgodny z praktyką przedstawicieli szkoły aleksandryjskiej.

Do budowania właściwej alegorezy przechodzi ojciec Wulgaty zazwyczaj wprowadzając terminus technicus ${ }^{28}$, którym w tym wypadku jest słowo tropologia ${ }^{29}$ :

„Mówi się więc według tropologii, że przy końcu świata lub śmierci każdego odejdzie od nas cała chwała i pycha Chaldejczyków oraz pogmatwanie świata, a wszystko tak zostanie zniszczone, jak Bóg zniszczył Sodomę i Gomorę, ani nie będzie już postaci świata tego, lecz przeminie na wieki (por. 1Kor 7, 31). Ani nie rozbije tam Arab namiotów swoich, o czym jest powiedziane w sześćdziesiątym siódmym psalmie: «Czyńcie drogę temu, który wstąił na zachód, Pan jego imię» (Ps 67, 5). I nie odpoczną tam pasterze, mianowicie aniołowie, którzy przewodzą rodzajowi ludzkiemu i codziennie widzą oblicze Ojca, lecz będą tam wypoczywać zwierzęta, smoki, strusie, kosmacze, puszczyki i syreny. Wszystkie te zwierzęta rozpoznajemy w postaciach aniołów albo demonów, tych, którym jesteśmy oddani, aby nas karać. A w domach, niegdyś przyjemnych, gdzie była wesołość i uciecha, będzie zawodzenie puszczyków, i godny pożałowania głos syren, które słuchaczy swoich prowadzą do śmierci. Natomiast ten, kto uważa, że w porównaniu do wieczności, wszelka długość czasu jest krótka i że w tych, którzy wierzą w Pana, Babilon jest codziennie burzony przez świętych mężów, w żaden sposób nie będzie zdziwiony, że bliski jest czas sądu i dzień końca Babilonu nie opóźni się. $\mathrm{Na}$ temat rodzajów zwierząt, a nawet potworów, powiedzieliśmy krótko, ponieważ częściowo zostały zwięźle objaśnione według znaczenia dosłownego

\footnotetext{
${ }^{28}$ Więcej na ten temat: P. Jay, Le vocabulaire exégétique de saint Jérôme dans le „Commentaire sur Zacharie”, REAug 14 (1968) 3-16.

${ }^{29}$ Tropologia (z gr. $\tau \rho o \pi \circ \lambda \mathrm{o} \gamma i \alpha$ ), nazywana też często sensem duchowym (łac. intelligentia spiritualis), polega na poszukiwaniu w tekście starotestamentowym treści chrystologicznych. Mówiąc o tropologii Hieronim sięgał do metafory wznoszenia się od sensu dosłownego, który nazywał po łacinie historia, fundamenta historiae lub litterae, ku znaczeniom wyższym. Por. Hieronymus, Epistula 120, 12, ed. I. Hilberg, CSEL 55, Wien - Leipzig 1912, 513-514, tłum. J. Czuj: Św. Hieronim, Listy, III, Warszawa 1954, 150-151. Samą terminologię egzegetyczną zaczerpnął ojciec Wulgaty z egzegezy aleksandryjskiej. Zob. L. Doutreleau, Introduction, w: Didyme l'Aveugle, Sur Zacharie. Texte inédit d'après un papyrus de Toura. Introduction, texte critique, traduction et notes, t. 1, SCh 83, Paris 1962, 55-64.
} 
w księdze wcześniejszej ${ }^{30}$. Trzeba jeszcze wziąć pod uwagę to, że mowa kościelna oraz nauka Zbawiciela obaliły miasto zamieszania w taki sposób, że porównuje się je z Sodomą i Gomorą - nie będzie zamieszkane przez świętych mężów, ani pasterze, którzy mają w zwyczaju wypasać stado Chrystusa, nie będą w nim wypoczywać, lecz przeciwnie: będą tam wypoczywać zwierzęta, smoki, strusie i kosmacze skakać w nim będą. Cokolwiek bowiem mówią heretycy w synagogach szatana, nie jest nauką Pana, lecz zawodzeniem demonów i kosmaczy, które naśladują Ezawa. A syreny wypoczywać będą w świątyniach przyjemności, których słodkie i śmiercionośne pieśni dusze wloką w otchłań, aby zostały pożarte przez wilki i psy, kiedy sroży się sztorm. Bliski jest więc i codziennie zbliża się czas klęski heretyków, a ich upadek nie będzie odroczony"31.

Złowrogie, pustynne, mające ciemne umaszczenie, często żerujące noca, na wpół demoniczne istoty są według św. Hieronima przeciwieństwem oswojonych i potulnych owiec Chrystusa. Zachowanie dzikich zwierząt, smoków, strusi i kosmaczy - wszystkich istot, które osiedliły się w ruinach przyrównanego do Sodomy i Gomory Babilonu - porównał Strydończyk do mowy heretyków, którą nazwał zawodzeniem demonów i kosmaczy. Warto dodać, że użyty tutaj łaciński rzeczownik ululatus to onomatopeja, która nawiązuje do dźwięku wydawanego przez sowy - puchania. Może też oznaczać wycie - dźwięk wydawany przez dzikie psy, wilki i kojoty ${ }^{32}$. Nauki heretyków są według św. Hieronima tożsame z naukami demonów, dlatego porównuje ich do zwierząt złowieszczych, które kojarzyły się z nieprzyjaznymi ludziom istotami nadprzyrodzonymi. Dla przykładu kosmacze (pilosi) mogły się kojarzyć z satyrami lub faunami ${ }^{33}$. Nauki heretyków zostały przez betlejemskiego mnicha porównane do słodkiego i zwodniczego głosu syren podczas sztormu, który swoich słuchaczy doprowadza do upadku. Celem heretyków - powie Hieronim - nie jest bowiem szukanie prawdy czy chęć niesienia pomocy drugiemu człowiekowi, a jedynie wykorzystanie bliźniego i sprowadzanie nań śmierci. Tutaj również spotykamy metaforę zwierzęcą - pożarcie przez wilki i psy. Jednak tak, jak upadek pysznego Babilonu się nie odwlekł, tak zbliża się czas nieuchronnej klęski heretyków.

Ojciec Wulgaty uważa heretyków za naśladowców Ezawa. Dlaczego? Wydaje się, że ma ku temu kilka powodów. Przywołajmy fragment jego Komentarza do Księi Abdiasza, który wystarczająco naświetli nam przyczyny takiego utożsamienia:

„W Księdze Rodzaju jasno czytamy, że Ezaw, syn Izaaka, został nazwany Edomem, ponieważ sprzedał pierworództwo za potrawę z czerwonej soczewicy

\footnotetext{
${ }^{30}$ Por. Hieronymus, Commentarii in Esaiam V 13, 20-22, VL 27, 559-560.

${ }^{31}$ Tamże VI 13, 19 - 14, 1, VL 27, 712-714, tłum. własne.

${ }^{32}$ Por. Oxford Latin Dictionary, ed. A.N. Bryan-Brown, Oxford 1968, 2087, s.v. ululatus.

${ }^{33}$ Por. Krzyszczuk, Wstęp, s. 540-543.
} 
(por. Rdz 25, 30-33). Bowiem Edom oznacza $\pi$ vóṕós, to jest czerwony. W tej samej księdze zostało również napisane, że został także określony jako Seir, to jest kosmacz, gdyż jego włosy były szczeciniaste i nie otrzymał łagodności Jakuba. Tak więc ta sama osoba jest określana trzema nazwami: Ezaw, Edom i Seir. [...] Tak więc dowiedzieliśmy się, że ziemia Idumejczyków jest wrogo nastawiona do ziemi obiecanej i czytamy, że Ezaw jest nieprzyjacielem Jakuba i że na jego lud Pan rozgniewał się na zawsze. Musimy także wiedzieć, że według praw tropologii słowa te są skierowane przeciwko Żydom, którzy są rywalami chrześcijan i prześladują swego brata, Jakuba. Są oni narodem fałszywym, który skradł pierworództwo. Słowa te są także skierowane przeciwko wszystkim heretykom i naukom przeciwnym prawdzie, które wydaja się być bliskie naszym, lecz które są im przeciwne. Usiłują one wydrzeć dziedzictwo Jakubowi, mieszkańcowi domu"34.

Według Komentarza do Księgi Abdiasza inne imiona Ezawa brzmiały Edom, co dosłownie znaczy czerwony ${ }^{35}$, oraz Seir, co można przetłumaczyć na ko$s m a c z$, owłosiony ${ }^{36}$. Imiona te nawiązują do fizjonomii starszego syna Izaaka - był rudy i owłosiony ${ }^{37}$. Taki wygląd najstarszego syna Izaaka może thumaczyć dlaczego ojciec Wulgaty w szóstej księdze Komentarza do Księgi Izajasza powiedział, że to właśnie kosmacze (pilosi) naśladują Ezawa. Jednak coś więcej niż wygląd wiąże Hieronimowych kosmaczy z bratem Jakuba. Opisany w Księdze Rodzaju konflikt Ezawa z Jakubem, jak słusznie zauważa ojciec Wulgaty, stał się w opinii proroków (por. Ez 35, 7; Am 1, 11; Ml 1, 2-4) obrazem konfliktu między narodami, których dwaj bracia byli protoplastami - Edomu i Izraela. Dla Hieronima Jakub alegorycznie oznacza chrześcijan, a jego starszy brat - wyznawców judaizmu, którzy prześladują Kościół dlatego, że stracili pierworództwo i nie są już narodem wybranym. Wszyscy zaś, którzy podejmują działania przeciwko Jakubowi, który jest synem i dziedzicem, czy to będą żydzi czy heretycy, poniosą słuszną karę.

Hieronim w wielu miejscach swoich komentarzy w taki właśnie sposób zestawia heretyków z wyznawcami judaizmu. Także w interesującym nas miejscu, w szóstej księdze Komentarza do Księgi Izajasza heretycy, których protoplastą i typem jest Ezaw, przemawiają w synagogach szatana. Jednym głosem przemawiają żydzi i heretycy. Dzieje się tak nie tylko dlatego, że Strydończyk oskarża jednych i drugich o wzniecanie prześladowań chrześcijan ${ }^{38}$,

${ }^{34}$ Hieronymus, Commentarii in Abdiam 1, 1, ed. M. Adriaen, CCL 76, Turnhout 1969, 354-355, thum. Ł. Krzyszczuk: Św. Hieronim, Komentarz do Księgi Abdiasza (Commentarii in Abdiam, CPL 589), VoxP 33 (2013) t. 60, 579-581.

${ }^{35}$ Por. Wielki słownik hebrajsko-polski i aramejsko-polski Starego Testamentu, red. L. Koehler - W. Baumgartner - J. Stamm, red. wyd. pol. P. Dec, t. 1, Warszawa 2008, 601, s.v. אֶדוֹ.

${ }^{36}$ Por. tamże, t. 2, 363, s.v. שֶׁעיעיר.

${ }^{37}$ Hieronim dodaje jeszcze, że czerwona była soczewica, za którą Ezaw sprzedał prawo pierworództwa Jakubowi.

${ }^{38}$ Por. Hieronymus, Commentarii in Abdiam 1, 10-11, CCL 76, 364, thum. Krzyszczuk, s. 590. 
ale też $\mathrm{z}$ tego powodu, iż wiele herezji chrześcijańskich miało proweniencję lub zabarwienie judaistyczne ${ }^{39}$.

Z przeanalizowanego powyżej fragmentu księgi szóstej Komentarza do Księgi Izajasza jasno wynika, że cechy powszechnie przypisywane istotom fantastycznym zostały wykorzystane przez św. Hieronima w tworzeniu polemiki antyżydowskiej i antyheretyckiej. Ojciec Wulgaty nie zdecydował się na rozstrzygnięcia trudnej kwestii realności istnienia smoków, syren czy onocentaurów. Powszechnie znane i często powtarzane informacje na ich temat skrzętnie wykorzystał do nakreślenia przed czytelnikiem obrazu heretyka. Zaczerpnięte $\mathrm{z}$ mitologii opisy istot, które pojawiają się w greckich przekładach heksaplarnych trzynastego rozdziału Księgi Izajasza, w ponaddosłownej warstwie komentarza aluzyjnie zestawił Hieronim z biblijną historią konfliktu synów Izaaka: Ezawa i Jakuba, który również rozumiał alegorycznie. Dzięki nawiązaniu do tej opowieści z Księgi Rodzaju lepiej rozumiemy dlaczego według egzegety ze Strydonu heretycy głoszą swoje zatrute nauki w synagogach. Dodajmy, że zestawianie heretyków z wyznawcami judaizmu jest w komentarzach do proroków św. Hieronima bardzo częste. Trzeba przyznać, że włączając polemikę antyżydowską i antyheretycką do swoich dzieł, ojciec Wulgaty pozostaje wierny tradycji aleksandryjskiej. Silną zależność Strydończyka od greckiej egzegezy aleksandryjskiej w Komentarzu do Księgi Izajasza dodatkowo potwierdza fakt, że budując alegorezę korzysta przede wszystkim z Septuaginty.

${ }^{39}$ Dla przykładu za heretyckie o zabarwieniu judaistycznym uznaje Hieronim poglądy millenarystyczne. Por. tenże, Commentarii in Zachariam III 14, 18-19, ed. M. Adriaen, CCL 76A, Turnhout 1970, 896-897: „Haec omnia quae nos celeri sermone perstringimus, Iudaei et iudaizantes nostri, immo non nostri, quia iudaizantes, sperant futura corporaliter, utique et circumcisionem sibi, et coniugia in mille annorum imperio promittentes, ne impleatur in illis maledictio quae scripta est: Maledicta sterilis quae non facit semen in Israel (Iz 31, 9, LXX) et: Beatus qui habet semen in Sion et domesticos in Hierusalem (Ps 50, 8)". Zob. tenże, Commentarii in Malachiam 4, 5-6, ed. M. Adriaen, CCL 76A, 942: „Iudaei, et Iudaizantes haeretici ante ì $\lambda \varepsilon \imath \mu \mu \varepsilon ́ v o v$ suum Heliam putant esse venturum, et restituturum omnia"; tenże, Apologia adversus libros Rufini II 33, ed. P. Lardet, SCh 303, Paris 1983, 194, thum. S. Ryznar: Św. Hieronim, Apologia przeciw Rufinowi, PSP 51, Warszawa 1989, 93. Por. M. Graves, ,,Judaizing” Christian Interpretations of the Prophets As Seen by Saint Jerome, VigCh 61 (2007) 142-156. 


\section{ANIMALIA DUBIA VEL FABULOSA \\ AS A CONTRIBUTION TO ANTI-HERETICAL POLEMIC \\ IN THE ST. JEROME'S COMMENTARY ON ISAIAH (VI 13:19 - 14:1)}

\section{(Summary)}

The article presents the way of using paradoxographical information regarding the matter of animals with doubtful identification in leading anti-heretical and Anti-Judaist polemic on the example of the sixth book Commentary on Isaiah by Jerome of Stridon. In the allegoric explanation of Is 13:19 - 14:1 Bethlehem monk juxtaposed widely known information about mythological creatures with the wellknown story from the Book of Genesis about the conflict of Esau with Jacob. This let him explain why the followers of Judaism and heretics are the allies when it comes to fighting with the Church. Anti-Judaism and anti-heretic polemic was one of the most important topic brought up by alexandrine exegesis that Jerome was influenced by during his whole life.

Key words: St. Jerome of Stridon, Commentary on Isaiah, antiheretical polemic.

Słowa kluczowe: św. Hieronim ze Strydonu, Komentarz do Księgi Izajasza, polemika antyheretycka.

\section{BIBLIOGRAFIA}

\section{Źródła}

Biblia Sacra iuxta Vulgatam versionem, ed. R. Weber - R. Gryson, Stuttgart $2013^{5}$.

Gaius Suetonius Tranquillus, De vita Caesarum, ed. M. Ihm: C. Suetoni Tranquillli Opera, vol. 1: De vita Caesarum libri VIII, Leipzig 1908, tłum. J. Niemirska-Pliszczyńska: Gajusz Swetoniusz Trankwillus, Żywoty Cezarów, t. 1, Wrocław 2004.

Hieronymus, Apologia adversus libros Rufini, ed. P. Lardet, SCh 303, Paris 1983, tłum. S. Ryznar: Św. Hieronim, Apologia przeciw Rufinowi, PSP 51, Warszawa 1989.

Hieronymus, Commentarii in Abdiam, ed. M. Adriaen, CCL 76, Turnhout 1969, 349-375, thum. Ł. Krzyszczuk: Św. Hieronim, Komentarz do Księgi Abdiasza (Commentarii in Abdiam, CPL 589), VoxP 33 (2013) t. 60, 574-601.

Hieronymus, Commentarii in Esaiam, ed. R. Gryson - P.-A. Deproost: Commentaires de Jérôme sur le prophetè Isaïe, vol. 1: Livres I-IV, Vetus Latina. Aus der Geschichte der Lateinischen Bibel 23, Freiburg 1993.

Hieronymus, Commentarii in Esaiam, ed. R. Gryson - J. Coulie: Commentaires de Jérôme sur le prophetè Isaïe, vol. 2: Livres V-VII, Vetus Latina. Aus der Geschichte der Lateinischen Bibel 27, Freiburg 1994.

Hieronymus, Commentarii in Malachiam, ed. M. Adriaen, CCL 76A, Turnhout 1970, 901-942.

Hieronymus, Commentarii in Zachariam, ed. M. Adriaen, CCL 76A, Turnhout 1970, 747-900.

Hieronymus, Contra Vigilantium, ed. J.-L. Feiertag, CCL 79C, Turnhout 2005, tłum. G. Rurański, w: Św. Hieronim ze Strydonu, Pisma polemiczne. Przeciw Helwidiuszowi. Przeciw Jowinianowi. Przeciw Wigilancjuszowi, ŹM 67, Kraków 2013, 429-457. 
Hieronymus, Epistulae, ed. I. Hilberg, CSEL 55, Wien - Leipzig 1912, tłum. J. Czuj: Św. Hieronim, Listy, III, Warszawa 1954.

Physiologus, ed. F. Sbordone: Physiologi Graeci singulae variarum aetatum recensiones codicibus fere omnibus tunc primum excussis collatisque, Mediolani 1936, thum. K. Jażdżewska: Fizjolog, Warszawa 2003.

Septuaginta, id est Vetus Testamentum graece iuxta LXX interpretes, ed. A. Rahlfs, Stuttgart 1979.

\section{Opracowania}

BARDSKI K., Alegoryczno-symboliczna interpretacja Biblii, Kraków 2016.

Bochart S., Hierozoicon sive de animalibus sacrae Scripturae, vol. 2, Londini 1663.

Doutreleau L., Introduction, w: Didyme l'Aveugle, Sur Zacharie. Texte inédit d'après un papyrus de Toura. Introduction, texte critique, traduction et notes, t. 1, SCh 83, Paris 1962, 13-188.

Drączkowski F., Patrologia, Pelplin 2012.

Fonck L., Hieronymi scientia naturalis exemplis illustratur, „Biblica” 1 (1920) fasc. 4, 481-499.

Grant R.M., Early Christians and Animals, London - New York 2001.

Graves M., Jerome's Hebrew Philology. A Study Based on His Commentary on Jeremiah, Supplements to VigCh 90, Leiden - Boston 2007.

Graves M., ,,Judaizing” Christian Interpretations of the Prophets As Seen by Saint Jerome, VigCh 61 (2007) 142-156.

Hagendahl H., Latin Fathers and the Classics. A Study on the Apologists, Jerome and Other Christian Writers, Studia Graeca et Latina Gothoburgensia 6, Göteborg 1958.

Heyman A., Sirens Chanting in Auvergne-Velay. A Story of Exegetical Pilgrimage on the Via Podiensis, „Ad Limina” 4 (2013) fasc. 4, 69-115.

JAY J., L'exégèse de Saint Jérôme d'après son „, Commentaire sur Isaïe”, Paris 1985.

J $\mathrm{AY}$ P., Le vocabulaire exégétique de saint Jérôme dans le „Commentaire sur Zacharie”, REAug 14 (1968) 3-16.

Kamin S., The Theological Significance of the Hebraica Veritas in Jerome's Thought, w: „Sha'arei Talmon”. Studies in the Bible, Qumran, and the Ancient Near East Presented to Shemaryahu Talmon, ed. M. Fishbane - E. Tov - W.W. Fields, Winona Lake 1992, 243-253.

Kelly J.N.D., Hieronim. Życie, pisma, spory, tłum. R. Wiśniewski, Warszawa 2003.

KrzyszczuK Ł., Wstęp, w: Św. Hieronim, Komentarz do Księgi Abdiasza (Commentarii in Abdiam, CPL 589), VoxP 33 (2013) t. 60, 557-573.

Krzyszczuk Ł., Wstęp, w: Św. Hieronim, Komentarz do Księgi Izajasza X 34, 1 - X 35, 10 (Commentarii in Esaiam, CPL 584), VoxP 36 (2016) t. 66, 527-551.

Labendz J.R., Aquila's Bible Translation in Late Antiquity. Jewish and Christian Perspectives, HTR 102 (2009) fasc. 3, 353-388.

Maisano R., L'esegesi di Girolamo ad Isaia, w: Seminario interdisciplinare sul libro del profeta Isaia, ed. R. Maisano - V. Mangogna, Napoli 2007, 101-146.

Mała encyklopedia kultury świata antycznego, II, red. Z. Piszczek, Warszawa 1962.

Miкоś K., Wiarygodność najstarszych przekazów greckich o Arimaspach $i$,ich” gryfach. Aristeasz, Herodot i kwestia starego Prokonnezu, w: Istoty hybrydalne i zmieniajace postać w kulturach europejskich i azjatyckich, red. K. Mikoś - K. Kleczkowska, Kraków 2015, 45-78.

Oxford Latin Dictionary, ed. A.N. Bryan-Brown, Oxford 1968.

Słownik grecko-polski, t. 1-4, red. Z. Abramowiczówna, Warszawa 1958-1965. 
Słownik łacińsko-polski, t. 1-5, red. M. Plezia, Warszawa 2007.

Thibaut A., La revision hexaplaire de Saint Jérôme, w: Richesses et deficiences des anciens psautiers latins, ed. P. Salmon, Collectanea Biblica Latina 13, Roma 1959, 107-150.

Wielki słownik hebrajsko-polski i aramejsko-polski Starego Testamentu, red. L. KoehlerW. Baumgartner - J. Stamm, red. wyd. pol. P. Dec, t. 1-2, Warszawa 2008.

Yuditsky A., Jerome's transcriptions of Hebrew. A reexamination, „Lešonenu” 76 (2014) 121-136. 